\title{
White Men Displace Red Men
}

\author{
By ORA WIILIAMS
}

When white men sailed across the Atlantic ocean four and a half centuries ago in search of a new route to India and the Orient, a continent was discovered on which red men lived. Christopher Columbus and his associates called these red men Indians, because he supposed they had really found India. The explorers who came later were nearly all looking for a route to India. Stories of fabulous riches in the far east spurred navigators to face the dangers of long voyages in unknown seas and kept hid the greater importance of newly found lands as fertile fields for colonies.

After awhile the urge for greater freedom of life and opportunity led to the taking over of the entire Atlantic coast for colonies of British, Dutch, French and Spanish origin, and the people of some of these colonies claimed the right to extend them clear across the continent. They did not know how large the continent was and thought it much smaller than it proved to be. Explorers continued to drive deep into the interior, some of them looking for places to live and others making search for a route to India through or around the continent.

That which is now Iowa was discovered as result of a military expedition sent out by the French government to find a great river, about which they had been told by Indians, and in the hope a route would be found to the Pacific ocean.

The colony of New France occupied the valley of the St. Lawrence river and reached to the west along the north shores of the great lakes. French traders were buying furs and French missionaries were teaching the Indians. For these purposes they desired to extend their influence as far as possible and also they wanted to keep ahead of the English and Spanish colonists who 
were rapidly taking possession of the central and southern parts of the North American continent. Men had at last come to realize the value of the soil and climate and natural resources of the midland region and rivalry for possession was active.

\section{Explorers View Iowa Area}

The discovery date for Iowa was June 17, 1673. On that day a little band of Frenchmen traveling in frail canoes rowed out into the Mississippi river and caught first sight of the hills and prairies of Iowa land. The exploring party was led by Louis Joliet, an officer who had been commissed by the governor of New France to find the river about which much had been heard. With him was Jacques Marquette, a Jesuit missionary who had long worked with the Indians. They had five others as assistants.

The party had started from Mackinaw, where a mission had been maintained and traders had their headquarters, had gone through Green Bay, followed the Fox river, then down the Wisconsin and on to the Mississippi near where McGregor became a settlement. They followed the current down the river and noted the addition of the waters of the Des Moines, the Illinois, the Missouri, the Ohio and the Arkansas rivers; then turned back and reacher their home. Father Marquette made report on the discoveries, but Joliet lost his records before he got back to Montreal.

The expedition had been warned by friendly Indians of the great danger of the journey, but on the contrary the explorers were delighted with the songs of birds and glimpses of wild herds and the quiet beauty of the scenery. When they had gone down the river "about sixty leagues" as they said, they found tracks made by human feet, and following the trail across the prairie they were greeted by Indians, who had a village near the mouth of the Des Moines river.

These Indians said they were Illini, which they said meant they were men and not savages, and they proved to be a family of the tribes living east of the river. 
Father Marquette could understand enough of their language so that friendly relations were at once established. They stayed for five days and the Indians entertained and feasted their visitors. They gave them a big dinner, after the Indian fashion, smoked the pipe of peace and urged the Frenchmen to come again.

The French people were good explorers and courageous adventurers. Joliet and Marquette and the French governor in America at once claimed all the land drained by the great river as a part of New France. Their report aroused intense interest and other expeditions were proposed. One of these was led by Hennepin, a missionary, who went up the river into what is now Minnesota and there met Du Luth, another French explorer, and together they returned by way of the Wisconsin river. This was in 1680. Two years later, La Salle went far down the river and named the country Louisiana, in honor of King Louis $\mathrm{XIV}$, who took much personal interest in these explorations.

\section{French Military in Control}

On learning there were mineral deposits along the river, Le Seuer led a small party of miners into the upper valley. The government of New France extended its military control to the Upper Mississippi and Nicholas Perrot established posts at Prairie du Chien and on Lake Pepin.

The missionary work among these Indians was not very successful, and the red men neither changed their religion nor their customs and refused to go to school. But the French did succeed in securing a valuable commerce in furs, and the Indians soon found it to their advantage to exchange the results of their hunting for blankets and weapons. French trade with the Indians extended into and all through Iowa and the northwest.

That which in now Iowa, although completely undiscovered, had first been claimed for the Spanish monarch by reason of the journeys of De Soto and others 
into the lands of the lower Mississippi. The Spanish and French claims hardly came into conflict. On one occasion a Spanish expedition was sent out from the southwest to dispute with the French the right to the midland region, but it failed.

The Spaniards held Florida and the coast of the Gulf of Mexico and established themselves at New Orleans. Finally they established settlements as far north as St. Louis where they entered the fur trade and sent forth explorers and missionaries.

The English colonies on the Atlantic coast laid claim to territory beyond the Allegheny moutains, but were in no position to assert their claims against the Indians, and made no attempt to extend their settlements into the interior of the continent. This attitude changed materially after the war between France and Great Britian in which the American colonies took active part.

Spain Acquired Louisiana

By the treaty of 1763, France gave up all of Canada to the British and New France passed out of existence. France still held nominal authority over Louisiana, which was along the Mississippi river with indefinite boundaries, and the King of France made a deal with the King of Spain by which the latter acquired Louisiana and all the rights of France. The Spanish rule was therefore extended from Florida and the gulf to the British possessions in western Canada and to the Rocky Mountains and including California.

From 1763 for a period of 37 years, Spanish authority was undisputed in Iowa and all along the west side of the Mississippi river. The Spanish trade centered in St. Louis and an important fur-trade was established there. The fur buyers traveled up the valleys of the rivers, including the Des Moines and others in Iowa. Generally friendly relations were maintained between the Spaniards and the Indians. The French and British traders continued to operate in the north and came into Iowa.

Indians showed samples of shiny ore to the white men 
and Julien Dubuque, a French adventurer, succeeded in finding where the ore came from; and he made friends of the Indians by marrying an Indian woman, and securing permission to do some mining. He opened a mine in Iowa, where now stands the city of Dubuque, took out and sold lead ore, and maintained a small colony of miners from the year 1788 until his death in 1810. He got some sort of a concession from the Spanish governor at St. Louis and called his business the "Mines of Spain." After his death the mines were reopened after lying idle twenty years and a permanent settlement was commenced.

\section{United States Buys Louisiana}

Louisiana became a part of the domain of the United States in 1803. The price paid was fifteen million dollars. That was an immense sum at the time, but it was a good bargain. It came about by reason of unavoidable complications. The Americans living in the Ohio valley found their best route to the markets of the world by boats down the Mississippi river. The Spanish authorities at New Orleans took advantage of this by imposing heavy charges on shipments made through that port. The disagreement on this matter became so serious that there was danger of war.

About this time the revolution in France brought Napoleon Bonaparte to the fore and he secured all of Louisiana from the Spanish, though the actual rule of the latter continued for a time. President Jefferson learned of the secret treaty by which ownership of Louisiana had been changed. The United States sent a representative to Paris and another to Madrid to bargain for shipping rights at the mouth of the Mississippi river, or perhaps to obtain a cession of New Orleans and thus to peaceably settle the disputes about commerce.

Bonaparte offered to sell all of Louisiana, and Livingston and Monroe closed the deal promptly. They had no authority to engage in any such immense land purchase, the president was embarrassed by a ter- 
ritorial expansion he had not expected, and the Spanish authorities at New Orleans and St. Louis were shocked and indignant. Neither did the Indians like it, for they had gotten along very well with both the French and Spanish.

The motive of Bonaparte, head of the French nation at the time, was to prevent the province from falling into the hands of the British and to strengthen the United States as against the British in the war through which he was already planning to dominate all of Europe. The Louisiana purchase was the greatest land deal in all history up to that time. It opened the way to extend the authority of the United States from ocean to ocean.

The treaty which gave Louisiana to the United States was signed in Paris April 30, 1803. The American representatives had gone far beyond their instructions, but their act was approved and before the end of the year the matter had been closed. Although Louisiana had been given to France, the Spanish control had continued for three years and the Spanish flag was flying at New Orleans and St. Louis. At first the Spanish government protested against the sale and at New Orleans there was threat of resistance. But on November 30, Spain formally turned over the province to France and three weeks later the French authorities placed the Americans in charge.

Not until March 9, 1804, was the Spanish flag hauled down at St. Louis and after the French flag had been flying for one day only, the American flag appeared and all of Louisiana came under the jurisdiction of the United States. Gov. William H. Harrison of Indiana territory took over and the new land was designated as the Louisiana district of Indiana, which included all to the Mississippi river. The lower part of Louisiana came under the jurisdiction of Mississippi territory as the district of Orleans. A year later the district of Louisiana was made Louisiana territory and Gen. James Wilkinson became governor. 
Learned of Area Acquired

The people of the United States were not prepared to cope with the big problems involved in the extension of the national domain into the unexplored regions of the far west. They set about to find out more about what they had purchased. An expedition was at once organized for that purpose. Meriwether Lewis, who had been secretary to President Jefferson, was placed at the head, and with him was associated William Clark, a military officer, and they led an exploring party up the Missouri river from St. Louis to its head in the mountains, then went on to the Pacific ocean. They started in 1804 and returned two years later. One of their party, Sergeant Charles Floyd, died and was buried on what later was called Sergeant Bluff, in Woodbury county.

The army officers recognized that military posts would soon be needed on the frontier and Zebulon Pike was sent from St. Louis with an exporing party in 1805 to select sites for forts along the Mississippi river. He went up to near the head of the river and back. He met several tribes of Indians and reported. As a result, the army built a military post and established a trading house at Fort Madison in 1808. The Indians objected to having a fort on the west bank of the river and Fort Madison was attacked and later abandoned. In 1816 the army established Fort Armstrong, on Rock Island, which was in the Illinois country. Not until 1834 was another military post planted in Iowa and this was Fort Des Moines, near the town of Montrose in Lee county.

The story of what happened in the Iowa area in the first thirty years after the United States secured possession is much like that of other regions where the red men were being forced to abandon their homes and hunting grounds in order that white men might cultivate the land and establish a new civilization. Much could be told about the conflicts and treaties with the Indians. The record made by the United 
States in dealing with the red men was not entirely creditable; but it must be remembered that at that time the Iowa region seemed very far away from the national capital, that information as to what was being done on the frontier was hard to get, and that there was much mutual dislike and hatred as between the pioneers and the Indians. However, the taking over of Iowa from the red men and preparation for organized government was accomplished in less time and with fewer disappointments or difficulties than in many other places. When the time came for the big rush for free lands in Iowa, the states south and east were well settled. Iowa was to be almost the last of the mid west regions to be settled by the covered wagon caravans, but the new trails into Iowa were not well defined nor heavily traveled.

Louisiana during the Spanish era was almost entirely in the actual possession of the Indians. Little effort was made to utilize the land. The Spanish authorities granted to Basil Giard a large tract of land in Clayton county, and a smaller tract to Louis Honore Tesson in Lee county. On the latter a small settlement was made and it was featured by the growing of a fine apple orchard said to have been planted by an Indian leader. Spain ceded Louisiana back to France in 1800 by a secret treaty, but the Spanish rule continued, with Spanish and French traders mingling freely and generally on friendly terms with the Indians.

Civilization Reaches Toward Iowa

By the close of the eighteenth century, civilization had moved up pretty close to the Iowa border on the east and south. The colonies from Florida to the St. Lawrence had become a new nation in 1776 and the region between the Ohio river and the lakes and west as far as the Spanish borders had become the Northwest territory. The Indian claims were being extinguished and territories organized with a view to becoming states. Home seekers were coming over the mountains and traveling into the west by steamboats 
or wagon trains. Military posts were located and towns grew up with stockades.

The fur trade had gone into control of great companies, but the pioneers were clearing the forests and turning the soil of the prairies to produce greater wealth. Not only had the great valleys of the Mississippi and Missouri been discovered but the trails led over the greater mountains of the far west and on to the western ocean. Within a few years all of the demand for more land would become irresistible. On the hunting grounds there would soon be American communities of industrious people.

\section{Iowa-Issued Dollar Comes Home}

A wandering Iowa-issued dollar bill of 1874 vintage at last came home in January, 1957. The dollar bill was issued in September, 1874, by the former First National Bank of Cedar Falls. Oddly, it turned up recently in a tin box belonging to a deceased customer of the National Provincial Bank, Ltd., in London.

The bill then was passed on to the London office of the Hanover Bank, New York, as "a memento of historical interest."

Forwarded to the Hanover's main office, the bill made the last leg of a long voyage home when it was presented to the present First National Bank, Cedar Falls, nearest "kin" to the original issuer, which failed in 1893.

The note still is worth a dollar, but it won't buy what it did 82 years ago. As a collector's item, it will bring more.

At that time, national banks could issue their own money on their holdings of treasury bonds. This practice was discontinued in 1935. 
Copyright of Annals of Iowa is the property of State of Iowa, by \& through the State Historical Society of Iowa and its content may not be copied or emailed to multiple sites or posted to a listserv without the copyright holder's express written permission. However, users may print, download, or email articles for individual use. 